\title{
Military Dictatorship in California and West Virginia
}

The Mexican people are not alone in their penchant for dictators. A striking illustration of how readily American citizens welcome, on occasion, a military dictator may be found in the history of San Francisco during and immediately after the great fire that followed the earthquake of April 18th, 1906. Martial law was not formally proclaimed, but the city was, in fact, for more than a week under the dictatorship of the Mayor, acting as a magistrate of authority as absolute as that of a captain over his ship, or an invading general in occupation of a hostile country during the time of war.

Early on the morning of April 18th, within two or three hours after the quake, General Funston, who held command in General Greeley's absence, had his troops marching from the Presidio to the scene of the fire, which already threatened to enroll itself as one of the world's greatest disasters. The soldiers were greeted with cheers by the people, and made a fine impression with their uniforms, full cartridge belts, fixed bayonets and steady tread. Against a human foe, threatening to invade the city, they would have been a splendid salvation, but against the fire, they might have proved more practically useful if they had left their guns and bayonets at home. Weapons taken from the arsenal of the bath room or the armory of the kitchen are better than bayonets for fighting fire, even when water mains are broken by an earthquake.

General Funston promptly turned his regulars over to Mayor Schmitz, for use during the emergency. The Mayor with the United States Army and the police force at his command did not wait for the Governor and the State militia to intervene, but at once seized all the power and 
assumed all the authority that he felt to be necessary to cope with the situation, even the power of life and death. The city was patrolled day and night by armed men, and for many days remained under the military dictatorship of the Mayor, advised and assisted by the "Committee of Fifty," appointed by himself, exercising supreme power over the property, the liberty and the lives of the citizens.

The most extraordinary measure from a legal point of view of this brief reign of martial law, which existed de facto, if not de jure, was the famous proclamation of the Mayor, made early on the first day of the fire, to the effect that:

"The Federal Troops, the members of the Police Force, and all special police officers have been authorized to kill any and all persons found engaged in looting, or in the commission of any other crime."

Such were the orders issued to the soldiers, which called for the peremptory taking off of any person detected in the commission of the slightest theft, without even a summary trial by a drumhead court martial. The numerous guards, national, state, municipal and civil supposed that they were authorized to shoot for looting, or for any hesitation in obeying their commands, and they occasionally did so.

It is reported by General Greeley that he had information of but nine cases of homicide, but there were doubtless others whose stories were wiped out by the fire. Among those recorded are the following:

Heber C. Tilden, a member of the General Relief Committee, was fatally shot by a squad of the citizens' patrol as he was entering the city by night in an auto flying the Red Cross flag.

One Myers, who was helping refugees encamped in a playground in the Mission, of which he had charge, and who advised the people contrary to a militia sergeant's suggestions about sending a party after supplies, was shot in his tracks for not departing rapidly enough when profanely ordered to "get out."

A foreign laborer was shot down in broad daylight on the waterfront and left wallowing for twelve hours on the street until he died. He had been arrested by a marine and a guard for taking chickens from a car which had been opened in premises surrounded by fire. He took the gun from the hands 
of the drunken marine, who was prodding him with the bayonet, and started to run away in wild terror, when the self-constituted guard raised his revolver and shot him, thinking he was doing his "military duty."

This sacrifice of human life was doubtless an indirect consequence of the reckless use of fire arms which had been ordered.

In its effect on the people at large, the most stringent and far reaching measure was the maintenance of fire lines by the soldiers. By these lines, tens of thousands of persons were restricted in their movements and prevented from entering their offices and homes for the purpose of saving their property. The orders were that people should be driven back from the burning buildings and should be kept at a distance of two blocks from the fire by strong detachments of troops. Business men going to save their records would find to their dismay that every approach to their offices was blocked. Often hours before the fire reached a locality, acting under the unbending orders of the military authorities, the soldiers would storm into a house, like a lawless mob, and order everyone to depart, threatening to shoot the occupants if they did not go. This is one reason why the people, for the most part, deserted their property where it lay in the path of the flames. as if it were a sacrifice laid on the altar, without ordinary efforts at rescue.

One writer, at least, has vigorously protested against this obstruction and interference by the soldiers, and asserts that it increased ten-fold the miseries and losses imposed on the city and the area reduced to desolation by the fire. ${ }^{1} \mathrm{He}$ tells dramatically how some houses on Russian Hill and Green street were saved, in spite of the military, the owners evading the efforts of the soldiers to expel them from their homes, or bribing them to be permitted to remain and extinguish the flames. In his words:

"During those days of the conflagration, the City of San Francisco was as a city captured in war, the possession of an

I See pamphlet published for private distribution by Henry Anderson Lafler, entitled "How the Army Worked to Save San Francisco." 
alien foe. We were strangers on our own streets, driven from our houses, gripped by the throat by a stupid soldiery and held fast till all our city burned."

It seems strange in looking back that no more organized effort was made by the citizens to fight fire and save movable property, as the flames advanced, and this is doubtless to be explained in part by the lack of a leader and in part by the apathy and despair induced by the policy of military obstruction.

The police may undoubtedly clear the streets from crowds in the vicinity of a fire and keep mere spectators from dangerous proximity or interference; but it is a novel exercise of authority to deny a man the right to save his belongings or defend his own home. What law is there to deny a man the right to risk his own life, if he will, in fighting fire?

However useful they may have been in relief work after the three days of fire, it seems certain that for the most part during the fire, the soldiers instead of aiding and assisting energetic citizens to fight the flames, rescued nothing, but with colossal stupidity put fatal hindrance in the way of saving valuable property that might have been saved. Whether this can be justified on the grounds of expediency is an interesting question for the historian of those days. It is not however, the purpose of this article to discuss the wisdom of the policy pursued in San Francisco or whether it increased or diminished the losses inflicted on the city by the fire. On this, opinions will differ. The question to be considered is how far the law justifies the assumption of such absolute authority as was exercised by military force in this great emergency to cope with conditions resulting from earthquake, fire, floods, or from strikes and labor wars such as from time to time demoralize the mining regions and tie up our street railway systems.

The Mayor of San Francisco is authorized by the charter to take all lawful measures for the preservation of public order and the suppression of riots and tumults, for which purpose he may command the police force. If that is insufficient he may call upon the Governor for military aid. But the calling out of the regular army by General Funston and its employment by the Mayor to execute his commands were entirely outside the constitutional scope of the army's duty. Even 
assuming that the city would have been in anarchy before the State guard could have reached the scene, the United States Army could not constitutionally intervene. The army may only be employed to protect states against domestic violence, under Article IV of the Constitution, on request of the State Legislature, or of the Governor, if the Legislature cannot be convened. ${ }^{2}$

Is it not an astounding state of affairs that the Mayor of a city should suddenly assume command of a regiment of federal troops by the consent of federal officers, and act independently of the Governor, who is the chief executive of the state? The Mayor or Sheriff, or Chief of Police are none of them authorized to call out even the National Guard of the State, without communicating with the Governor, who is the commander-in-chief. The State Constitution places in the Governor's hands the command of the militia, and the sole power of judging and determining when such danger of riots, disorder and bloodshed has arisen as makes it incumbent upon him to call forth the military power of the state to preserve the public peace. If the militia are called out, the governor or his military representative becomes supreme in command. ${ }^{3}$

In San Francisco there was no condition of war, riot, or disorder. But it may be argued that the extraordinary emergency of the fire and great danger of panic and disorder called for martial law as much as widespread rioting and mob violence, so that the full military power of the governor for the public defense might be invoked.

Can the governor of a state in case of serious rioting or public danger which he calls out the militia to meet, declare a "state of war" to exist and place the town, district, or county affected under martial law? The courts of this country have gone to a dangerous extreme in upholding such authority,

2 In the exercise of federal authority, however, the army of the nation and all its militia may interfere directly to restrain forcible obstruction of the highways along which interstate commerce travels and mails are carried. In re Debs. (1895) 158 U. S. 564.

${ }^{3}$ Chapin v. Ferry, (1891) 5 Wash. 386; 28 Pac. 754, 15 I. R. A. 116. 
but none so far as the Supreme Court of Appeals of West Virginia in the recent case of State ex rel. Mays v. Brown. ${ }^{4}$ The governor of West Virginia by his proclamation set off a portion of Kanawha County on Paint and Cabin Creeks, where serious trouble between striking miners and the mine owners had occurred, as a martial law district, in which he declared a "state of war" to exist, and called out the state militia to quell the riotous disturbances therein. Mays and Nance, citizens of West Virginia, resident in the martial law district and not connected with the military service, a few days before the proclamation. were accused of having committed certain statutory offenses connected with the rioting amounting under the law only to misdemeanors. ${ }^{5}$ They were arrested by the militia, tried by military commission pursuant to order of the governor, sentenced to terms of two and five years to the state penitentiary and transported there to serve their respective terms of sentence. The criminal court having jurisdiction over the county was sitting far from the seat of the rioting and was wholly unaffected in its powers. No necessity justified superseding the ordinary constitutional tribunals or prevented the transportation of Nance and Mays out of the riotous district to the court set for trial, except that the governor so ordered.

The governor had presumed to authorize the issuance of a military order by which he substituted his own arbitrary will for the law, government and constitution, and improrised a tribunal to punish all offenders at its discretion. This is the order:

“State Capitol, Charleston, November 16, 1912.

"The military commission is substituted for the criminal courts of the district covered by the martial law proclamation and all offences against the civil laws as they existed prior to the proclamation of November 15, 1912 shall be regarded as offences under the military law, and as a punishment therefor the military commission can impose

4 (Feb. 25, 1913), 77 S. E. Rep. 243.

5 Mays is said to have been accused of assaulting a workman in this district, though this does not appear in the report. 
such sentences, either lighter or heavier than those imposed under the civil law, as in their judgment the offender may merit."

Üpon petition for habeas corpus by the prisoners against the warden of the state penitentiary, the Supreme Court of Appeals of West Virginia, Robinson, J., dissenting, held that the prisoners were in lawful custody under commitment and sentences by the military commission appointed by the governor, and they were remanded to prison. As Robinson, J., in an able dissenting opinion says, "no court ever before upheld the action of a governor in ousting the courts of their jurisdiction and in substituting himself therefor."

Martial law, as understood by Americans generally is simply the calling out of the militia to aid the police. Martial law is defined by the West Virginia court, however, as the will of the military chief, in this instance the governor of the state, acting as commander of the militia. In other words he becomes an absolute dictator without law, with an army to execute his arbitrary will, and with no liability for assumption or abuse of power but impeachment by the legislature. The disturbance "sets aside, suspends, and nullifies the actual operation of the constitution and laws. The guaranties of the constitution as well as the common law and statutes. and the functions and powers of the courts and officers, become inoperative by virtue of the disturbance." In the face of express provisions of the constitution against suspending the writ of habeas corpus, that no citizen not in military service shall be tried by military courts for offenses cognizable by the civil courts, and that the provisions of the constitution are operative alike in a period of war as in a time of peace and are not to be departed from on the plea of necessity, this court upheld a military dictatorship, deriving the power by implication from the provision for a military organization, from the authority conferred upon the governor to call out the militia to execute the laws and suppress insurrection, from the implied retention of the public right of self-defence and from the necessity of the thing.

The celebrated case of ex parte Milligan, in which the 
sentence of a military commission was held void by the United States Supreme Court is distinguished because Indiana was tranquil territory, not covered by any proclamation of martial law. Martial law is operative only in such parts of the country as are actually at "war." If the governor has power to declare a "state of war," his action in doing so is not reviewable by the courts.

The power to establish a military commission for the summary trial and punishment of persons arrested within the military zone is a necessary incident and instrumentality of martial government, says the court. Indeed it would seem to follow that men could be shot down without even a trial by court martial, simply on military orders, as the San Francisco proclamation directed in the case of looters and all other criminals caught in the act.

It may be suggested that the governor certainly does not use the militia to enable him to execute the laws if he takes upon himself legislative power to suspend the constitution, create crimes and prescribe punishments by military edicts, erect tribunals of his own and punish citizens without due process of law. Even aside from the stringent provisions of the West Virginia constitution, no state can proceed in this way in the face of the Fourteenth Amendment.

The decision of the majority, per Poffenbarger, President, is based on the preposterous notion that the governor of a state may declare a state of war and adopt the usages of war in suppressing an insurrection, by which is no doubt meant a serious riot. This idea is supported by some misleading language of Taney, C. J., in Luther v. Borden, ${ }^{7}$ not essential to the decision, the error of which was pointed out in that very case by Woodbury, J., dissenting.

In the very recent case of "Mother" Mary Jones and others, ${ }^{8}$ arising from the same reign of martial law in Kanawha

7 (1849), 7 How. 1.

8 Ex parte Jones, 77 S. E. 1029 (Supreme Court of Appeals, W. Va., March 21, 1913.) 
County, the basic principles and conclusions announced in the case of Mays and Nance were elaborately re-examined, approved and re-affirmed. The prisoners in this case were charged by the provost marshal with conspiracy to inflict bodily injury, and with other offenses within the district covered by the governor's proclamation of war. They were arrested in the City of Charleston, outside of the district, by a civil officer, brought within it, and delivered into the custody of the military authorities to await trial by military commission, and probably conviction and confinement in the state penitentiary without indictment or trial by jury.

On habeas corpus they sought to be turned over to the civil authorities for trial, but the majority of the Supreme Court of Appeals held that this detention of the prisoners. although they were arrested outside of the military district, was entirely valid and legal, and they were remanded to the custody of the military authorities, acting under the control and direction of the governor.

As Robinson J., put the question presented in this case in his dissenting opinion: "May citizens accused of civil offences be tried, sentenced and imprisoned or executed by military commissions at the will of the governor of this state, notwithstanding the civil courts having jurisdiction of the offence are open?"

There is an intimation in the majority opinion that the actual decision only authorizes military arrest and detention until the disturbances are suppressed. It was intimated that the end of martial law might terminate the prison sentences. But as Robinson $J$. points out, if this was all that the majority meant to hold, why did they not say in plain words,-- "You may arrest and detain to overcome the exercise of hostile force, but you cannot by military court send rioters to the penitentiary."

The extended argument of the majority does not seek merely to justify preventive arrest and detention until violence is overcome. It all aims to uphold the broad claim that the governor has power to declare a state of war in any town, district or county in the state, suspend the constitutional guarantees, deal with citizens as if they were alien enemies in war, and substitute the rule of executive force for the rule of law to such an extent that the power of the courts to control the 
executive arm is suspended. The court indeed suggests that there may be limits beyond which the executive could not go without subjecting himself or his officers to rights of action for damages on restoration of peace, but no attempt is made to define these limits or to enumerate what offences are cognizable by military commission, or to measure the extent of the punishment which it may infict. So far as the principles laid down are concerned, the governor may, when the ordinary courts are open, issue orders to his officers to cause any persons to be tried in a summary manner and to be punished by death or otherwise in their discretion.

It is recognized by the majority that as a result of the principles and views advanced by them there may be two areas or sections in the state, by virtue of a declaration of war over a certain district, in which the powers of governor and the rights of citizens differ most radically. As soon as a riot starts martial law may be declared and every man, woman and child residing in the "war" district will be deprived of all constitutional rights, state and federal, and subject at once to the arbitrary rule of a dictator who is legislator, judge and executioner.

It is obviously of the utmost importance to clear away such dangerous misconceptions as are shown by these cases, which lead to the assumption of unauthorized powers, the infliction of grievous wrongs, and the incurring of serious liabilities civil and criminal, and to ascertain the source and scope of military authority over the persons and property of individuals.

Military authority varies with the government exercising it, and with the place, the person and the occasion of its exercise, and these various occasions have not been adequately distinguished. A rough classification is as follows, under which we may discriminate military authority as exercised:-

A. By the federal government.

1. For the internal discipline of the regular military and naval forces, known as military law;

2. Military government exercised by an invading general over the inhabitants of enemy territory;

(a) Aliens in foreign territory;

(b) Rebels given the character of public enemies in hostile domestic territory; 
(c) Inhabitants of subjugated domestic or foreign territory after war until Congress acts.

3. Over citizens in loyal territory in the military commander's own country in time of war,

(a) On the actual theatre of war;

(b) On the theatre of military operations in time of war;

(c) In pacific districts in time of war outside the theatre of military operations.

4. Over citizens in putting down riot and insurrection.

B. By the States, which have no war power but merely power to use the militia to conserve the peace.

The failure of the majority of the West Virginia Court to observe any distinction between the kind of military authority exercised by the federal government or by a state, between the war power and the power to conserve the peace, between what a military commander may impose on the inhabitants of hostile territory which he occupies in time of war and what he may impose on loyal citizens in domestic territory, results in the most extraordinary misapplication of principles and authorities. Those relating to the nation engaged in a public war are applied to a state suppressing domestic disorder among its citizens. It is said, "The declaration of a state of war was in law and in fact a recognition or establishment of belligerency and made the inhabitants of the military district technically enemies of the state."

May our own citizens be given the status of public enemies, without action of the war-declaring power? "By war is meant an armed conflict of public nature, the parties to which are recognized as belligerents entitled to all the rights and subject to all the obligations which international law recognizes and imposes." If war exists all the people of the districts at war become enemies, all partnerships are dissolved and all commercial intercourse is suspended. Civil strife may become of

92 Willoughby Constitution of the United States, Section 714; Prize Cases, (1862) 2 Black 635. 
such alarming proportions as to lead to war. But in our Constitution the power is lodged in Congress to declare war; to it belongs the authority to affix to a civil struggle the character of public war and possibly also to the President, but certainly not to the governor of a state. A state of the Union has not the constitutional power to declare war or create a state of war. ${ }^{10}$ The situation of the state militia accordingly is entirely different from that of troops in an enemy's country in a public war, ${ }^{11}$ and it is not correct to say that war conditions existed in West Virginia. The military authorities were subject to the Constitution and to state law; they could not appeal to the rules of international law which define the rights and usages of war between the belligerent power and the inhabitants of invaded enemy territory. Furthermore the dicta in Luther vs. Borden ${ }^{12}$ that the Supreme Court could not question the authority of the state of Rhode Island to declare martial law were uttered before the adoption of the Fourteenth Amendment.

The war power of the Federal Government justifies the exercise of martial rule even within places in the military commander's own country in a civil war if the national army is occupying territory whose inhabitants have been given the status of public enemies by Congress. As to them the war power is subject to no limitations of the Constitution but only to such as are imposed by the law of nations. ${ }^{13}$ But whether the war power is without limitations in loyal domestic territory, even on the theatre of actual military operations, is another question. "Over all persons and property within the sphere of actual military operations, he may lawfully exercise such restraint and control as the successful prosecution of his particular military operation may in his honest judgment absolutely require."14 In other words, with reference to all

102 Willoughby on the Constitution, Sec. 730.

11 But compare misleading dicta in Com. v. Shortall, (1903) 206 Penn. State 165, 55 Atl. 952, 65 I. R. A. 193.

12 (1849) 7 How. 1.

13 Miller v. U. S., (1870) 11 Wall. 268.

14 B. R. Curtis, Pamphlet on "Executive power," (1862); Compare Col. H. C. Carbaugh, Martial Law, 7 Ill. Review 479, 495, (irarch 1913). 
those not having the status of public enemies the war power is limited by the requirements of military necessity, which will be reviewed by the courts. ${ }^{15}$ "It is an unbending rule of law that the exercise of military power, where the rights of the citizen are concerned, shall never be pushed beyond what the exigency requires." 16

When the militia of the state are called out, or when federal troops are putting down riots and mob violence, they exercise no war power, but only the public right of self defence, using military force so far as may be reasonably necessary to subdue open violence and protect life and property. The military authorities may indeed be authorized to make preventive arrests and detain rioters temporarily, instead of handing them over to the civil authorities at once, if this seems to be a proper means of restoring peace and order against those who would aid and abet a continuance of the disturbance if at liberty. This is not a suspension of the writ of habeas corpus, but is a possible ground for a court to deny release under habeas corpus or damages for false imprisonment. ${ }^{17}$ But the finding of guilt and the fixing of the punishment of rioters and criminals is not the function of the soldiery. The true view undoubtedly is that during a riot or other disturbance militiamen and their officers are authorized to act merely as a body of armed police with the ordinary powers of police officers. This is as far as the actual decision goes in Luther vs. Borden. The governor of a state, as commander of the militia, is merely the chief conservator of the peace and entirely destitute of power, whether in tranquil or in riotous and rebellious districts, either to proclaim war or martial law, supersede the courts, or subject citizens to arbitrary military orders which he unreasonably believes to be demanded by "public emergency." 18

15 Mitchell v. Harmony 13 How 115.

16 Raymond v. Thomas, 91 U. S. 712.

${ }_{17} \operatorname{Re}$ Moyer, (1906). 35 Colo. 159; 85 Pac. 190; 12 L. R. A. (N. S.) 979; Moyer v. Peabody (1909) 212 U. S. 78; In re Boyle (1899), 6 Idaho 609, 57 Pac. 706, 45 L. R. A. 832.

${ }^{18}$ Franks vs. Smith 142 Kentucky 232, 134 S. W. 484; See the writer, "Martial Law," 12 Columbia Law Review 529; (June, 1912). 
A proclamation of martial law or a "declaration of war" can make no difference in the situation whatsoever. The prosecution and punishment of rioters, even if taken flagrante delicto belong to the tribunals of the law and not to the sword and bayonet of the military.

That a state court should sanction the idea that the constitution, state or federal, may be set aside or declared inoperative in riotous districts at the will of the governor; that the governor has power not only to suspend all statutes, but issue edicts in their place; that an improvised tribunal of militia officers when the courts are open, may be allowed to try, sentence, and execute citizens while still inflamed with the conflict,- this is an abdication of the supremacy of law only equal to that of the English judges who held that the crown might by royal prerogative suspend laws without the consent of Parliament and that the king was the sole judge of such necessity. Such a decision well justifies the Kern resolution calling for a senatorial investigation of conditions, an act recognizing that it is a national question whether the liberties, privileges and immunities of citizens of the United States under the Constitution are not to be respected by the States, and whether military dictatorship can exist in America unchallenged.

HENRY WINTHROP BALLANTINE.

University of Montana, Missoula, Montana. 